\title{
Impact of parasites on the reproduction and fecundity of the blue sand crab Portunus pelagicus from Moreton Bay, Australia
}

\author{
Jeffrey D. Shields*, Fiona E. I. Wood \\ Department of Parasitology, The University of Queensland, St. Lucia, Queensland 4072, Australia
}

\begin{abstract}
The rhizocephalan Sacculina granifera had a marked effect on the gonad development and growth of its host Portunus pelagicus (L.). Crabs were frequently castrated by the parasite, but, in some cases, castration was incomplete. That is, the reproductive potential of the infected host is not necessarily zero. Infected hosts were also capable of mating and, in a few cases, actually produced egg clutches. The impact of mating between uninfected and castrated crabs has not been previously established; sterile matings represent a further cost to the host population. Crabs were susceptible to infection by the parasite at any size/age, but juvenile crabs were more frequently infected with sacculina interna than mature and last instar adults. The abundance of the egg predator Carcinonemertes mitsukurii was correlated with salinity and temperature, but not with egg mortality on the host. Hence, the worms had little impact on host fecundity. The nicothoid copepod Choniosphaera indica was the major source of egg mortality on P. pelagicus. Mean mortality due to the copepod was $2.4 \%$ with a range of 0 to $19.6 \%$. While the copepod may be capable of rapid development and infection of crab clutches, it had a negligible effect on host fecundity because it occurred at relatively low intensities ( 1 to 1821 copepods host ${ }^{-1}$. The parasite and egg predators exhibited seasonal patterns in their infections of the host population. To assess the impact of the parasites on the reproductive biology of $P$. pelagicus, we examined crab maturation, mating, molting, gonad development, fecundity, and brood mortality. Crabs mature at 79 to $90 \mathrm{~mm} \mathrm{CW}$ (carapace width, inside the epibranchial spines). The molt increment and percentage change in size between molts did not vary between sexes for the carapace width but did vary between sexes for the chelar merus length. Seasonal patterns were found in the molting, mating, gonad development, breeding, and sex ratios of crabs.
\end{abstract}

\section{INTRODUCTION}

The blue swimmer or sand crab Portunus pelagicus (L.) is distributed from the eastern Mediterranean to east Africa in the Indian Ocean, and to Japan and Tahiti in the western and south Pacific Ocean (Stephenson \& Campbell 1959). It supports one of the largest crab fisheries in the world. In 1980, the market for the crab was estimated at \$US 150 million (Haefner 1985). Moreton Bay is the historical center for the commercial fishery in Australia (Thomson 1951, Sumpton et al. 1989a). Landing records are available from 1937

\footnotetext{
- Present address: CBNERRS-VA, Virginia Institute of Marine Science, Gloucester Point, Virginia 23062, USA
}

(Thomson 1951), with recent annual catches in Moreton Bay estimated at 2 million crabs per year (Smith \& Sumpton 1987).

Past studies of Portunus pelagicus have reported on the population structure, abundance, catch statistics, diet, reproductive biology, and migrational patterns of the crab (Thomson 1951, Rahaman 1967, Pillai \& Nair 1971, 1976, Williams 1982, 1986, Potter et al. 1983, Devi 1985, Campbell \& Fielder 1986, 1988, Smith \& Sumpton 1987, Sumpton et al. 1989a). Few studies have addressed the potential impact of parasites on crab reproduction and fecundity, yet, there are several parasites that may impact on populations of the crab through host castration and brood mortality.

The rhizocephalan barnacle Sacculina granifera is a known parasitic castrator of Portunus pelagicus 
(Phillips \& Cannon 1978). The barnacle has been reported at relatively high prevalences of 6.6 to $29 \%$ (Thomson 1951, Phillips \& Cannon 1978. Weng 1987. Shields 1992). A good account of the effect of the parasite on male crabs, and the morphometry of chelar propodus length and carapace width is given by Phillips \& Cannon (1978), with changes in the morphology of the abdomen detailed by Weng (1987). The behavioral ethogram of infected and uninfected males shows that they behave more like females (Bishop \& Cannon 1979).

The nemertean Carcinonemertes mitsukurii is an egg predator of Portunus pelagicus (Humes 1942, Shields 1992). Taxonomic relatives of C. mitsukurii have caused catastrophic egg mortality on several different crab populations; they have been implicated as possible causal agents in the decline of the Alaskan red king and central California Dungeness crab fisheries (Wickham 1986, Kuris et al. 1991). The nicothoid copepod Choniosphaera indica is also an egg predator of $P$. pelagicus (Gnanamuthu 1954), but little is known of its potential impact on populations of its hosts. Estimates of cgg mortality and the potential imnact of the egg predators on populations of $P$. pelagicus have not been previously determined.

In order to assess the impact of the parasites on the reproductive biology of Portunus pelagicus, we undertook a study of crab maturation, mating, molting, fecundity, and brood mortality. Seasonal fluctuations in gonad indices, the proportion of ovigerous crabs in the population, sex ratios, and molt conditions and the size at maturity for male and female crabs were examined. We then focused on the parasites that were known to affect reproduction and examined their relationship with the reproductive biology and fecundity of their host.

\section{MATERIALS AND METHODS}

Crabs were collected at night from an area near Brisbane in Moreton Bay, Australia, by the University of Queensland RV, 'The Sea Wanderer'. All of the trawls ( $n=24$ ) were between the mouth of the Brisbane River north to the mouth of Cabbage Tree Creek, in 5 to $7 \mathrm{~m}$, with one exception from Bramble Bay (1 February) and 2 northwest of St. Helena Island (12 June and $17 \mathrm{July}$ ). Twin Yankee Doodle otter trawls were used with an average time of 10 to $15 \mathrm{~min} \mathrm{trawl}^{-1}$ at a cruising speed of 2.6 knots as in Shields (1992). Collections were made 1 to 3 times per month during 1990, and 951 crabs comprising 519 mature females, 78 immature females, 250 mature males, and 104 immature males were examined and dissected. Monthly sample sizes were: Jan, 68 crabs; Feb, 64; Mar, 55; Apr, 101; May, 109; Jun, 57; Jul, 107; Aug, 41; Sep, 125;
Oct, 67; Nov, 94; Dec, 63. Our collection method was biased for mature crabs.

Crabs were examined externally and internally as in Shields (1992). Briefly, their size [carapace width (CW, excluding epibranchial spines, also known as short carapace width), and merus length of the cheliped, MER], sex, and condition (ovigerous, limb regeneration, sacculina externa) were noted. Live crabs were cooled to $4{ }^{\circ} \mathrm{C}$ until they became torpid ( 30 to $45 \mathrm{~min}$ ); their carapaces were then removed for dissection. The midgut, hindgut, ventral nerve ganglia and portions of the hepatopancreas and gonads were examined for parasites.

The maturity of the crabs was determined by the CW-MER relationship, and a semi-quantitative gonad index. For male crabs, the index was the relative development of the testes (see Fig. 5B). For females, 2 indices of maturity were used: the color and relative development of the ovary in the hemocoel; and the fullness of the seminal receptacles (see Fig. 4C). In addition, the ovigerous condition or, in some cases, infestation by Carcinonemertes mitsukurii on the branchial lamellae were also used to indicate maturity of the crabs.

The molt stage of each crab was determined as in Kuris (1975) and Johnson (1980, p. 388). The gill cleaner (epipod of the first maxilliped), gill lamellae, and the relative hardness of the carapace of the crab were examined to derive the molt stage (i.e. A to $E$ of Drach 1939). For the statistical analyses, the molt stages were grouped according to molt condition (i.e. post-molt or $A$ to $C_{3}$, inter-molt or $C_{4}$, and pre-molt or $D_{1}$ to $D_{4}$ ). Crabs undergoing ecdysis were placed in the post-molt condition for statistical treatments. To examine molt increments, the carapace widths and merus lengths of crabs that had molted in the laboratory were measured to the nearest $0.1 \mathrm{~mm}$. A total of 22 crabs molted in the laboratory, 10 females and 12 males. Ten of the these were pubertal molts 13 females and 7 males). The merus lengths of only 14 molted crabs were measured due to the loss or damage of chelae.

Fecundity and egg mortality were measured as in Kuris et al. (1991). After preservation in 10\% formalinseawater, a sub-sample of approximately 1000 eggs was clipped from the pleopod and the total number of live and dead eggs were counted. For each pleopod the egg-bearing setae were agitated for $3 \mathrm{~min}$ in tap water to remove parasites which were then decanted, identified and counted. The eggs remaining on the setae were cut free, examined for parasites, then placed on filter paper (Whatman \#1 or \#4) (sample and subsample, separately) and dried at $45^{\circ} \mathrm{C}$ for 3 to $4 \mathrm{~d}$ before being weighed. Fecundity, the number of eggs per clutch, was estimated by dividing the total weight of the eggs by the weight of the counted sample. 
Fecundity outliers were excluded on the basis of infection by Sacculina granifera (known parasitic castrators) or incomplete oviposition in the laboratory.

Prevalence is the proportion of infected versus uninfected hosts; mean abundance, the mean number of parasites for both uninfected and infected hosts; and mean intensity, the mean number of parasites per infected host (Margolis et al., 1982). Statistical tests (regression, ANOVA, ANCOVA, $G_{H}$-tests) are from Sokal \& Rohlf (1981). For the analysis of fecundity, crab embryogenesis was classed as early, middle or late as in Shields et al. (1991). For the analysis of season, months were classed as summer (January to March), fall (April to June), winter (July to September) and spring (October to December)

Salinity and temperature were measured with a refractometer and thermometer at the time of capture or shortly thereafter. Salinity measurements from Toondah Harbor differed by approximately 3 to 4 ppt from those from the collection site but the trends were identical, hence the data were corrected and combined for the analysis (supplied by Chris O'Brien, The University of New South Wales, Australia).

\section{RESULTS}

\section{Maturity}

Most mature crabs had a carapace width greater than $90 \mathrm{~mm}$, and a merus length greater than $40 \mathrm{~mm}$. The minimum size for a mature male based on the presence of fully developed testes was $81 \mathrm{~mm} \mathrm{CW}$. The minimum size for a mature female was either $79 \mathrm{~mm}$ CW based on inseminated seminal receptacles, or $82 \mathrm{~mm}$ CW based on the presence of an egg clutch (Fig. 1). The following equations were used to convert long carapace width (LCW, with epibranchial spines) into short carapace width (SCW, without spines): male, $\mathrm{SCW}=0.88 \mathrm{LCW}-5.25$; female, $\mathrm{SCW}=0.85 \mathrm{LCW}-$ 2.69 (Potter et al. 1983).

Merus length was strongly correlated with carapace width in mature and immature crabs of both sexes (Fig. 2). The relationship did not vary between immature and mature females (ANCOVA, among slopes, $F_{\mathrm{s}}=1.888, \mathrm{p}<0.001, \mathrm{df}=57,388$ ), but was significantly different between immature and mature males $\left(F_{\mathrm{s}}=27.484, \mathrm{p}<0.001, \mathrm{df}=83,189\right)$, between mature males and females $\left(F_{\mathrm{s}}=576.468, \mathrm{p}<0.001\right.$, $\mathrm{df}=$ $189,388)$, and between immature females and males $\left(F_{\mathrm{s}}=14.772, \mathrm{p}<0.001, \mathrm{df}=57,83\right)$. The CW-MER relationship was examined between Sacculina graniferainfected (hereafter castrated) and uninfected crabs, since infection by rhizocephalans is known to affect secondary sexual characters in crustaceans. While the
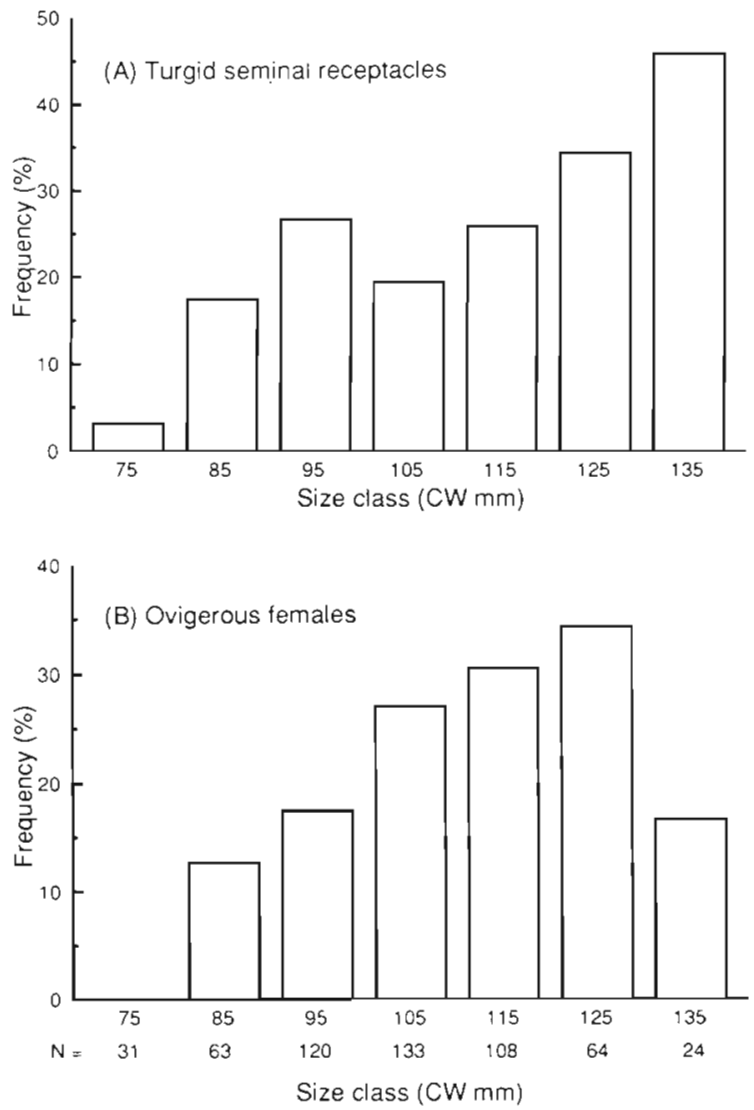

Fig. 1 Portunus pelagicus. Size-frequency (\%) histograms of maturity of female crabs as determined by (A) recent mating (turgid seminal receptacles) and (B) breeding (the ovigerous condition)

CW-MER relationship was not significantly different between castrated and mature uninfected females $\left(F_{\mathrm{s}}=\right.$ $0.054, p>0.90, d f=61,388$ ), it was highly different between castrated and mature uninfected males (Fig. 2; ANCOVA, among slopes, $F_{\mathrm{s}}=46.354, \mathrm{p}<0.001$, $\mathrm{df}=35,189$ ), but only weakly significant between castrated and immature females $\left(F_{\mathrm{s}}=5.464, \mathrm{p}<0.025\right.$, df $=$ $8,57)$. The relationship was also not significantly different between castrated and immature male crabs $\left(F_{\mathrm{s}}=\right.$ 1.577, $\mathrm{p}>0.05, \mathrm{df}=10,83$ ).

The molt increment (the difference between the premolt and post-molt size) for carapace width averaged $16.1 \mathrm{~mm}$ (3.4 mm SD) and showed no significant difference between sexes. The molt increment for merus length was, however, significantly larger in males than females $(13.7 \pm 4.2 \mathrm{~mm}$ vs $6.2 \pm 2.6 \mathrm{~mm}, t=4.12$, $\mathrm{p}<0.01, \mathrm{n}=9$ and $\mathrm{n}=5$ ). Castrated crabs held in the laboratory for various periods were not observed to molt.

The molt increment of the carapace did not change significantly between molts. There was, however, a significant negative correlation between the pre-molt carapace width and the percentage change in carapace width [defined as: 1 minus the quotient of the 

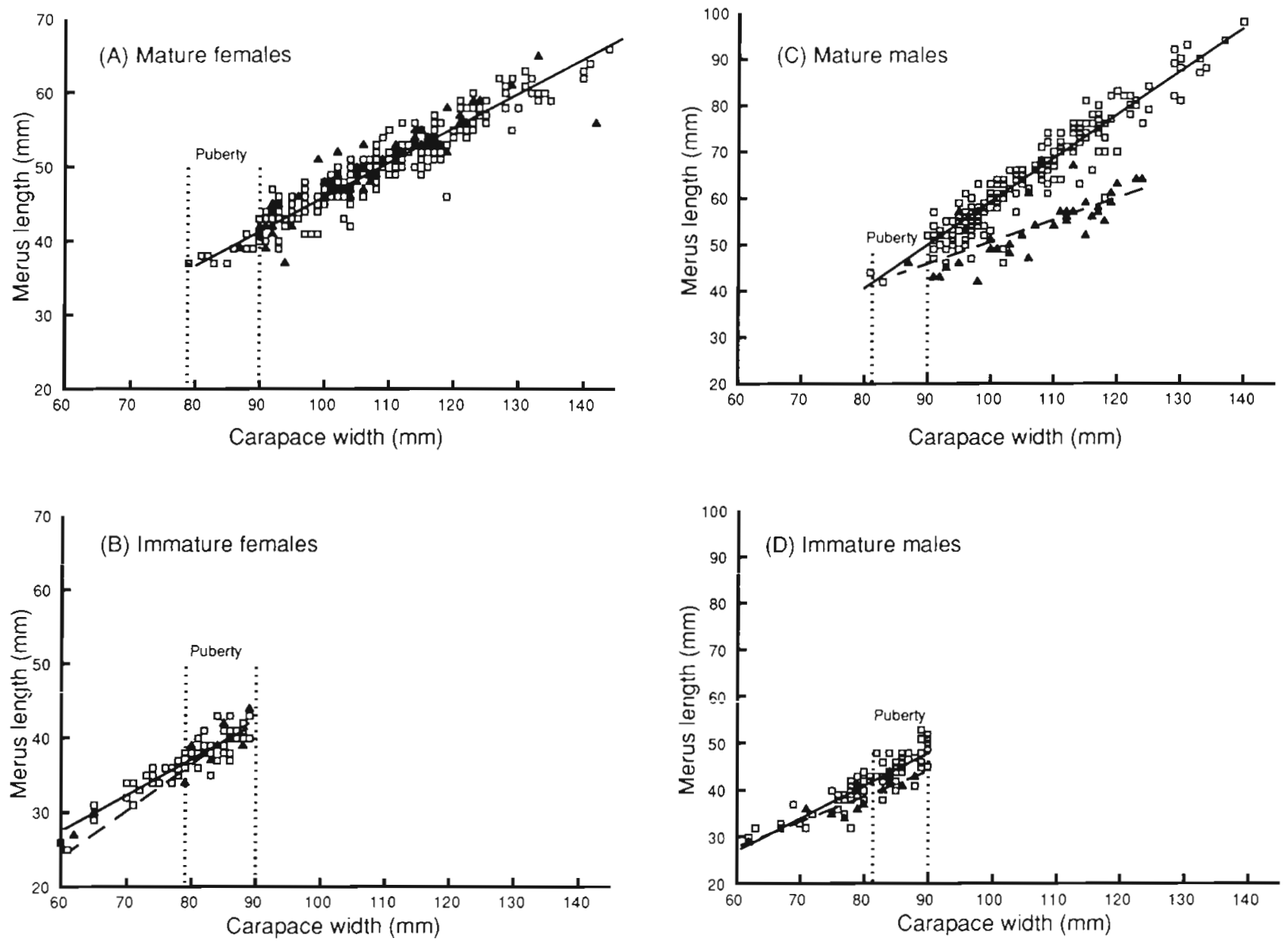

Fig. 2. Portunus pelagicus. The chelar merus length-carapace width relationship for (A) mature female crabs, (B) immature female crabs, (C) mature male crabs, and (D) immature male crabs. Note change in $y$-axis with sex. $(0,-)$ uninfected crabs; $(\boldsymbol{\Lambda},---)$ Saccuina-infected crabs. Regression equations were: mature females, $y=0.453 x+0.964, \mathrm{r}=0.934, \mathrm{p}<0.001, \mathrm{df}=389$; infected females, $y=0.459 x+0.566, \mathrm{r}=0.917, \mathrm{p}<0.001, \mathrm{df}=62$; juvenile females, $y=0.505 x-3.299, \mathrm{r}=0.921, \mathrm{p}<0.001, \mathrm{df}=58 ;$ infected juvenile females, $y=0.638 x-14.004, p<0.01, \mathrm{df}=9$; mature males, $y=0.940 x-35.090, \mathrm{r}=0.948, \mathrm{p}<0.001, \mathrm{df}=190 ;$ infected males, $y=0.472 x+3.730, r=0.730, p<0.01, d f=36$; juvenile males, $y=0.679 x-12.943, r=0.904, p<0.001, d f=84 ;$ infected juvenile males, $y=0.546 x-4.96, r=0.883, p<0.01, \mathrm{df}=11$

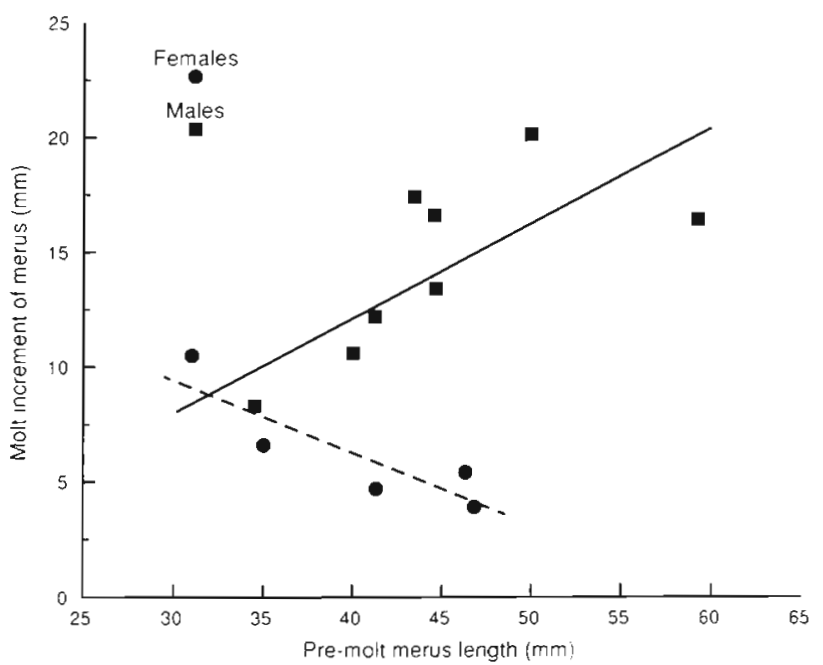

post-molt size divided by the pre-molt size $\times 100(y=$ $301.5-180.9 x, \mathrm{r}=0.640, \mathrm{p}<0.001, \mathrm{n}=22)]$, and between the post-molt carapace width and the percentage change in carapace width $(y=257.6-130.6 x, r=$ $0.422, p<0.03$ ); i.e. the proportional change decreased with increasing crab size. There were also weak but significant correlations between merus length and molt increment between sexes; males had a positive relationship, and females, a negative relationship between merus length and molt increment (Fig. 3). Accordingly, females possessed a much smaller merus than males.

Fig. 3. Portunus pelagicus. The molt increment-pre-molt merus length relationship. Regression equations: males $(y=24.3$ $+1.4 x, r=0.728, p<0.02, \mathrm{df}=7)$, and females $(y=54.8-2.4 x$, $r=0.834, p<0.05, d f=3$ ) 


\section{Seasonality}

Molting, mating, gonad development and egg deposition were all linked and showed distinct seasonal patterns (Figs. 4 \& 5). Crabs molted and mated throughout most of the year except during the late winter and early spring months of July through September when mating activity declined (Figs. 4B \& 5B). The gonad index for mature male crabs showed a peak in the summer months, while the gonad index for mature female crabs showed a maximum in the winter months just prior to the spring peak in egg laying. Ovigerous crabs occurred in every month except June. The proportion of females bearing eggs had a bimodal distribution with a large peak in August and September and a small peak in February and March.

The sex ratio also showed a significant fluctuation with season (Fig. 6). There were significantly more mature female crabs collected than mature male crabs in every month but May and June. The shift towards a 1:1 sex ratio coincided with the apparent peak in mating (May-June, turgid seminal receptacles) and with the decline in the number of mature crabs caught in the trawls (Figs. 4 \& 5).

Salinity and temperature showed consistent fluctuations with seasons (Fig. 7). Salinity decreased in relation to rainfall during April to June. The minimum monthly temperature was positively correlated with the proportion of females with ripe ovaries (Stage 5) and the proportion of males with full testes (Stage 3) (Spearman rank, $r_{\mathrm{s}}=0.580, p<0.05$, and $r_{\mathrm{s}}=0.864$, $\mathrm{p}<0.01, \mathrm{df}=10$, respectively). Salinity was not correlated with any of the reproductive variables.

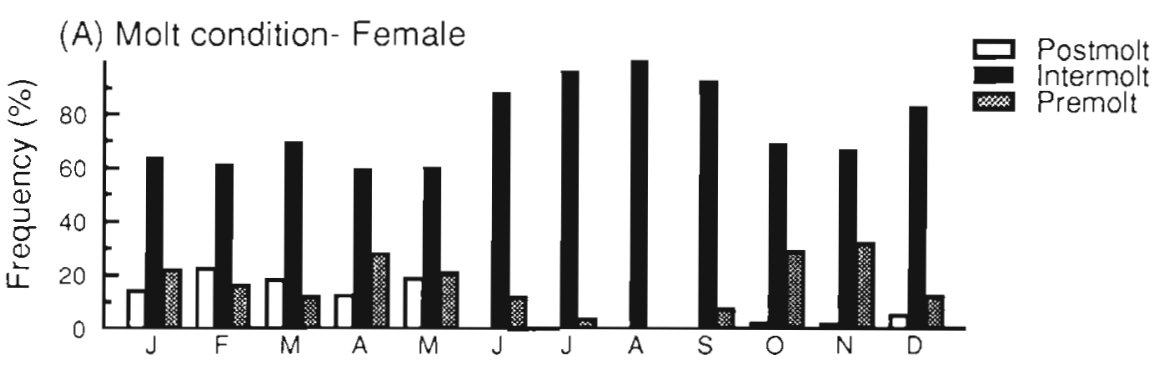

(B) Seminal receptacles

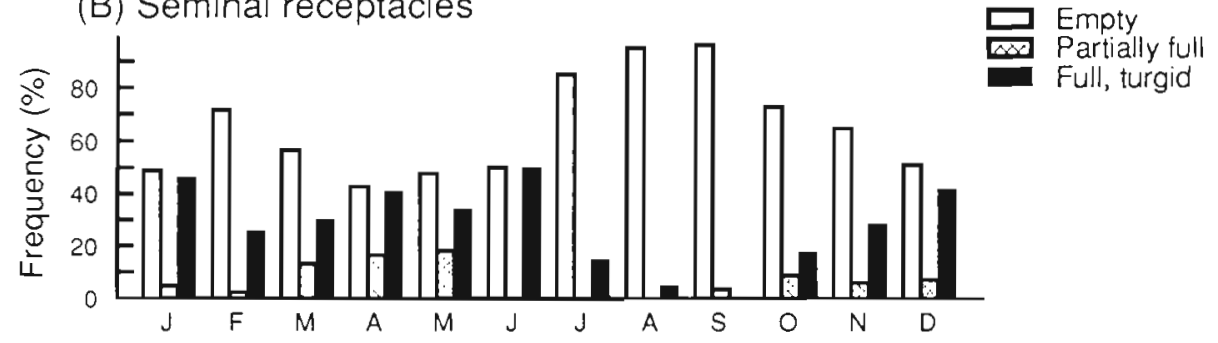

(C) Ovarian development

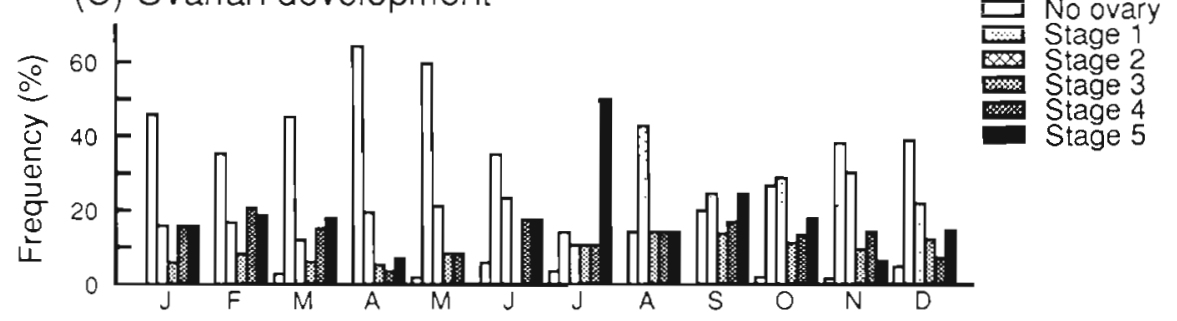

(D) Ovigerous females

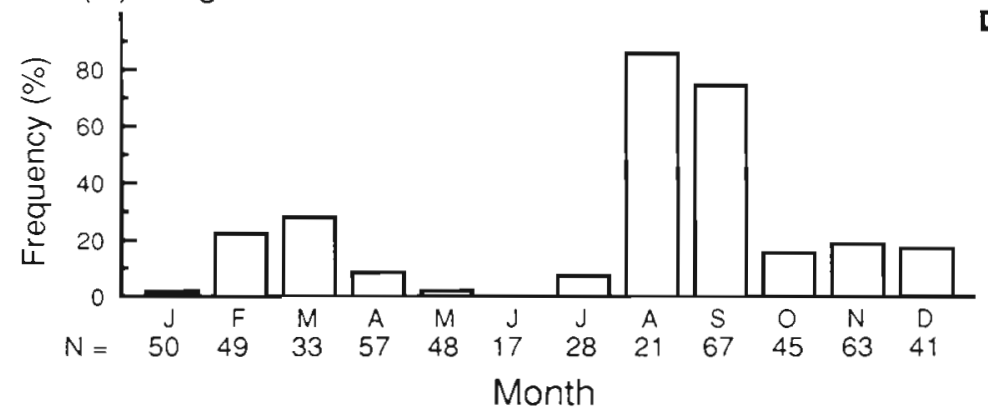

Fig. 4. Portunus pelagicus. Seasonal fluctuations in the reproductive parameters of female crabs: (A) molt condition; (B) seminal receptacle index: empty or flaccid, half full, or full and turgid; (C) ovarian index: (0) not present, (1) white and microscopic, (2) tan and $\leq 1 / 4$ of the hemocoel, (3) yellow and $\leq 1 / 2$ of the hemocoel, (4) taupe and $\leq 3 / 4$ of the hemocoel, or (5) orange and $>3 / 4$ of the hemocoel; and (D) proportion of ovigerous crabs. N: no. of mature females examined each month

\section{Fecundity and egg mortality}

Crab fecundity was linearly correlated with carapace width (Fig. 8). Fecundity ranged from 103000 to 1880000 eggs per crab, and did not change significantly during embryogenesis (ANOVA, $F=0.16$, $p>0.80, d f=2,116)$. Fecundity fluctuated with season but the trend was not significant (ANOVA, $F=1.58$, 


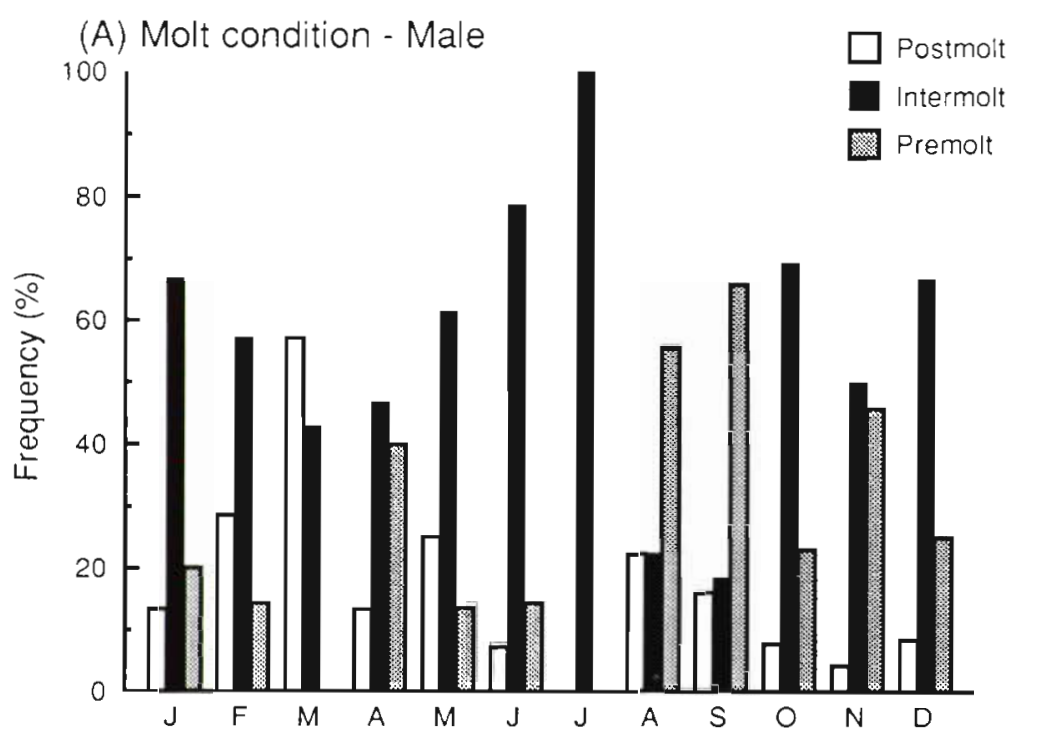

(B) Testicular development

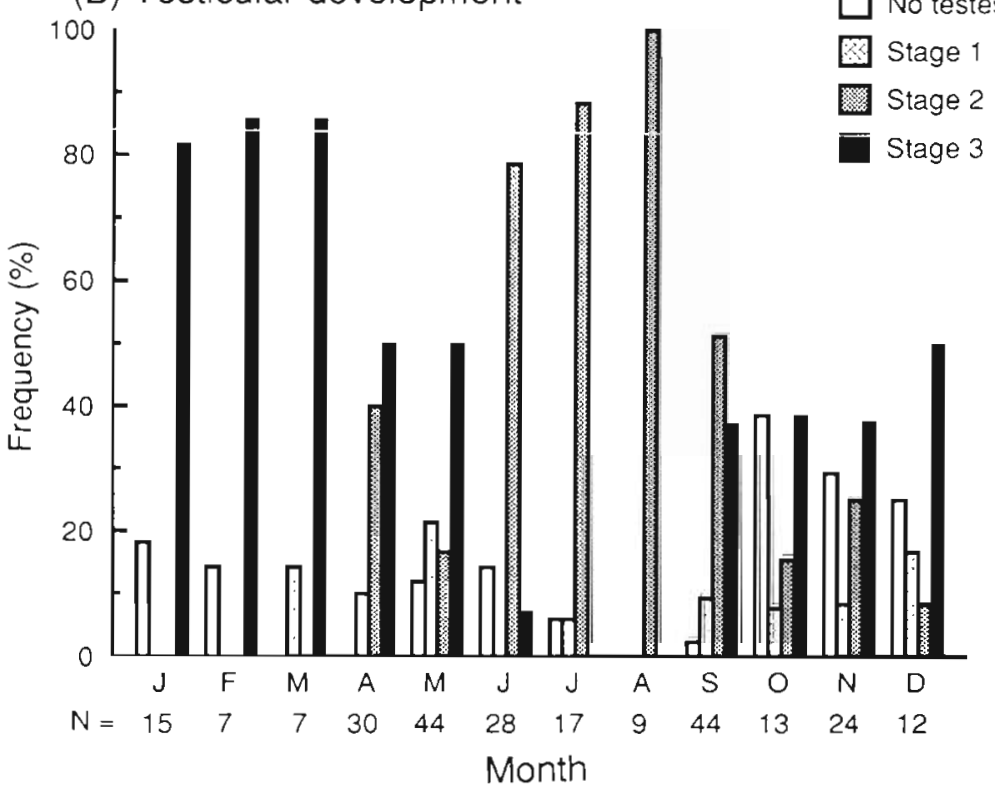

Fig. 5. Portunus pelagicus. Seasonal fluctuations in the reproductive parameters of male crabs: (A) molt condition, and (B) testicular development: (0) not present, (1) empty of mature sperm, (2) partially developed, or (3) fully developed, turgid with sperm. N: no. of mature males examined each month

not significant). Egg mortality was strongly correlated with the intensity of the copepod infestation (i.e. uninfected hosts excluded, $r=0.331, p<0.001, n=98$ ) but not with that of the nemertean $(\mathrm{r}=$ 0.042 , not significant, $\mathrm{n}=52$ ). The mortality due to abrasion and other sources was estimated at $1.64 \pm 0.40 \%(\mathrm{SE})(t=4.12$, $\mathrm{p}<0.001, \mathrm{n}=116$ ) using the $y$-intercept of the regression equations for the abundance of egg predators on egg mortality.

\section{Parasites and egg predators}

Crabs infected with Sacculina granifera showed differences in the allometry of their growth (see Fig. 2). Infected male and juvenile crabs had signifirantly lower molt increments (measured by the $\mathrm{CW}$ MER regression) than did their uninfected counterparts. Infected females did not experience lower molt increments than their uninfected counterparts.

Gonad development of mature crabs was significantly affected by the rhizocephalan (Table 1). Infected male crabs possessed either microscopic testes or no testes with the exception of 4 of 41 infected crabs. While infected females had a significantly lower index of ovarian development, 6 of 72 infected females possessed ovaries in advanced stages of development. Indeed, 2 of 123 ovigerous crabs had sacculina externae in the intermediate stages of growth, and another ovigerous crab possessed dead sacculina rootlets.

Infection by the rhizocephalan did not affect mating. No significant differences were observed in the proportion of infected female crabs with turgid seminal receptacles compared with their uninfected counterparts $(26.4 \%$ vs $27.8 \%$,

$p>0.10, d f=3,118$ ). In the laboratory, crabs were capable of ovipositing 1 to 2 additional broods.

Egg mortality from predators (Carcinonemertes mitsukurii and Choniosphaera indica) or abrasion ranged from 0.0 to $19.6 \%$ (excluding embryos near hatching, and 2 cases of infertility). Mean mortality varied from $0.7 \%$ early in embryogenesis to $4.9 \%$ in later stages. Such mortality was weakly correlated with the abundance of the nicothoid copepod Choniosphaera indica ( $\mathrm{r}=0.185, \mathrm{p}<0.05, \mathrm{n}=116 \mathrm{crabs}$ ), but not with the abundance of Carcinonemertes mitsukurii $(r=0.001$, respectively, $\left.\chi^{2}(2)=0.147, p>0.90\right)$. The proportion of female crabs with sacculina externae with full receptacles was not significantly different than that of females with sacculina internae $\left(\chi^{2}{ }_{(4)}=0.606, p>0.19\right)$. The externa of infected crabs may not hinder mating because the externa is miniscule just after the crab molts.

There was a difference in the size of crabs infected with sacculina interna versus sacculina externa (Fig. 9). The prevalence of sacculina interna was higher in juvenile crabs than in mature crabs $\left(G_{H}=\right.$ 


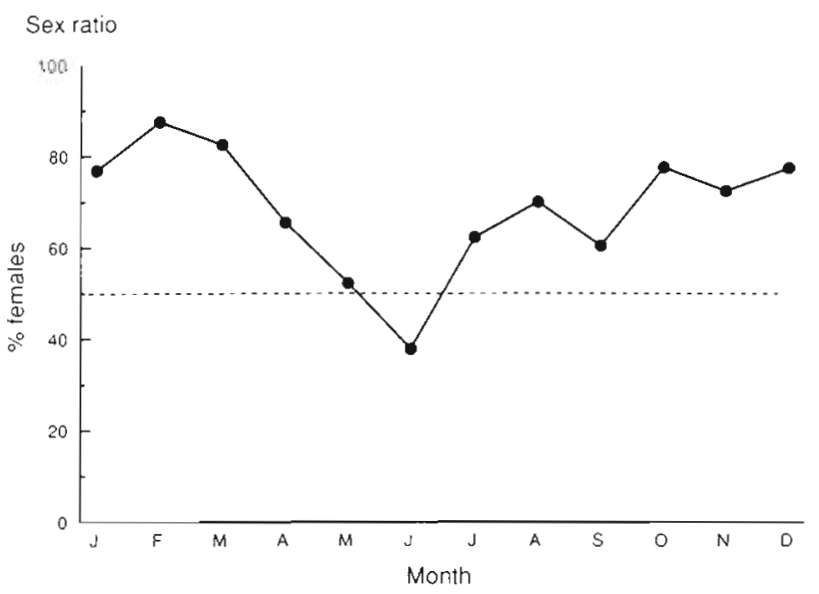

Fig. 6. Portunus pelagicus. The sex ratio as the percentage of mature female crabs in the mature population for each month. The dotted line represents a sex ratio of $1: 1$. Sample sizes for mature crabs are given in Figs. $4 \& 5$

33.64, $\mathrm{p}<0.001$, $\mathrm{df}=1$ ). Sacculina interna were, however, found in 2 large crabs, and young externa were found in 4 large crabs, indicating that they may be susceptible to infection at any age.

The prevalence of Sacculina granifera fluctuated with season (Fig. 10A) and was highest in June-July and October-November. Fluctuations in the prevalences of infection with season were not significantly different between host sexes. There was an increase in the abundance of sacculina interna (the early stage of infection) from April to October with a peak in July (Fig. 10B). Mature and senescent (flaccid or effete) externae of the parasite occurred throughout most of the year but were more abundant November through March.

Table 1 Sacculina granifera infecting Portunus pelagicus Comparison of the gonad indices of mature and immature uninfected and parasite-infected crabs. Gonad development was reduced or ceased in all of the infected crabs. The semiquantitative gonad indices are defined in Figs. 4 \& 5

\begin{tabular}{|c|c|c|c|c|}
\hline \multirow{2}{*}{$\begin{array}{l}\text { Ovarian } \\
\text { index }\end{array}$} & \multicolumn{2}{|c|}{ Mature females } & \multicolumn{2}{|c|}{ Immature females } \\
\hline & Uninfected & Infected & Uninfected & Infected \\
\hline 0 & 1 & 7 & 7 & 3 \\
\hline 1 & 164 & 33 & 49 & 7 \\
\hline 2 & 91 & 23 & 0 & 0 \\
\hline 3 & 44 & 3 & 2 & 0 \\
\hline 4 & 62 & 5 & 3 & 0 \\
\hline 5 & 80 & 1 & 2 & 0 \\
\hline \multirow{2}{*}{$\begin{array}{l}\text { Testicular } \\
\text { index }\end{array}$} & \multicolumn{2}{|c|}{ Mature males } & \multicolumn{2}{|c|}{ Immature males } \\
\hline & Uninfected & Infected & Uninfected & Infected \\
\hline 0 & 5 & 24 & 14 & 4 \\
\hline 1 & 16 & 7 & 39 & 8 \\
\hline 2 & 90 & 6 & 37 & 0 \\
\hline 3 & 91 & 4 & 0 & 0 \\
\hline
\end{tabular}

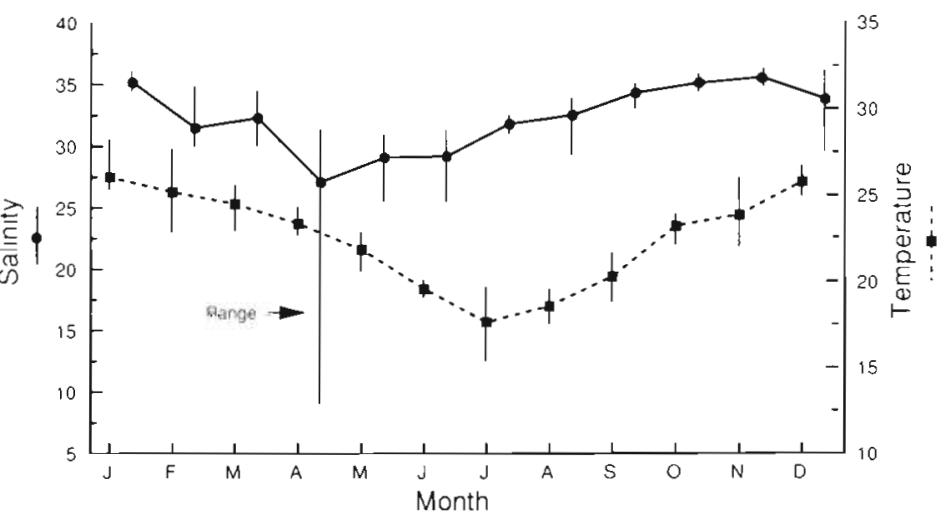

Fig. 7. Seasonal profiles of temperature $\left({ }^{\circ} \mathrm{C}\right.$ ) and salinity (ppt) in Moreton Bay (1988 to 1990). Data from C. O'Brien, Centre for Marine Science, University of New South Wales, Austalia and the present study

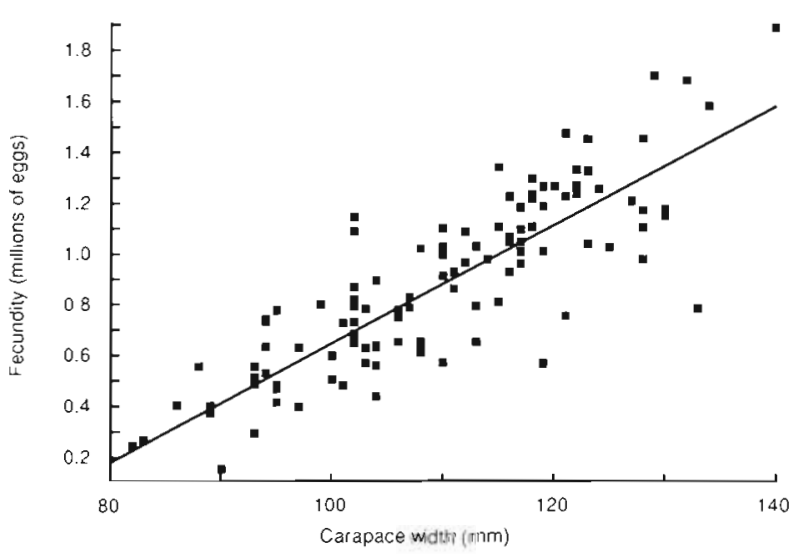

Fig. 8. Portunus pelagicus. The size (carapace width)-fecundity relationship of crabs. The relationship with log(fecundity) is not shown. Regression equation: Fecundity $=22809 \mathrm{CW}$ $-1631855, \mathrm{r}=0.811, \mathrm{p}<0.001, \mathrm{df}=113 ; \log ($ fecundity $)=$ $3.145 \log (C W)-0.510, r=0.745, p<0.001)$

The molt condition of the host was significantly influenced by infection with Sacculina granifera. A significantly greater proportion of infected hosts were found in the intermolt condition than uninfected hosts $(69.8$ vs $61.8 \%, G_{H}=26.95, \mathrm{p}<0.001, \mathrm{df}=4, \mathrm{n}=136$ and 815). The proportion of crabs with externae in the intermolt condition was significantly greater than that of crabs with internae $\left(86.0\right.$ vs $48.3 \%, G_{H}=22.55$, $\mathrm{p}<0.001, \mathrm{df}=2, \mathrm{n}=78$ and 58) which, in turn, was significantly less than that of uninfected hosts in the intermolt condition $\left(G_{H}=6.86, p<0.05, \mathrm{df}=2\right)$. Crabs with externae were occasionally found in the premolt ( 8 of 78 crabs), or postmolt condition ( 3 of 78 ), but their externae were small and in the early stages of growth.

The overall prevalence of Carcinonemertes mitsukurii on female crabs was $40.1 \%$, with $42.6 \%$ of the ovigerous crabs infested. Infestations ranged from 1 to 865 worms. Nemerteans were rarely found on immature crabs, males, and castrated females ( 4 of 182,4 of 250 . 


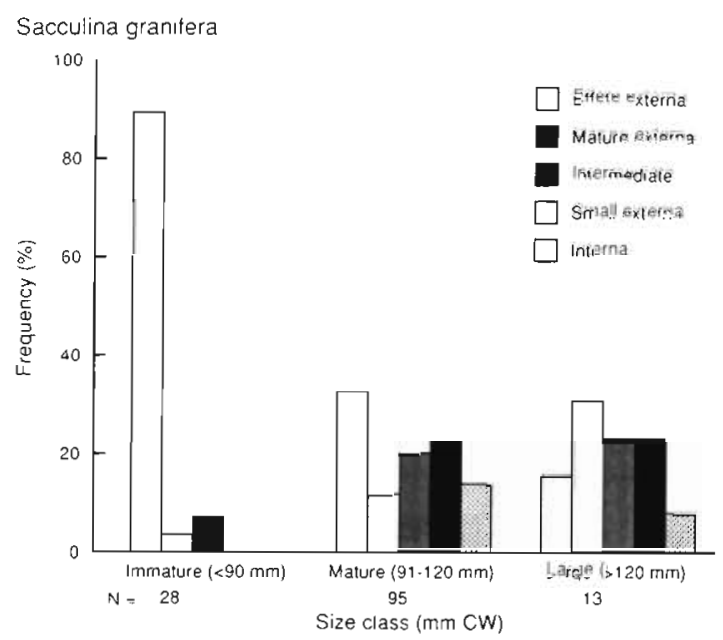

Fig 9. Sacculina granifera in Portunus pelagicus. Size-frequency $(\%)$ histogram of in infected juvenile $(<90 \mathrm{~mm} \mathrm{CW})$, mature $(91-120 \mathrm{~mm} \mathrm{CW})$, and last instar (>120 $\mathrm{mm} \mathrm{CW}$ ) crabs
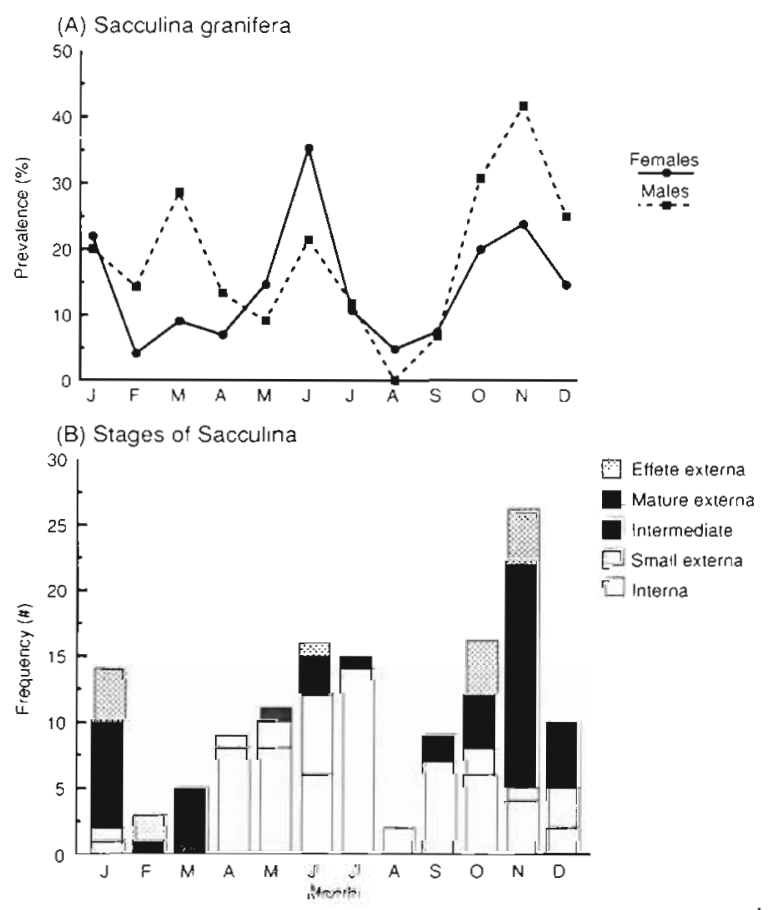

Fig. 10. Sacculina granifera in Portunus pelagicus. Seasonal fluctuation in (A) parasite prevalence in relation to the sexes of crabs, and (B) the frequency (\#) of different stages of the parasite. Note the peak in sacculina internae in June and the peak in externae in November Sample sizes for male and female crabs are given in Figs. 4 \& 5

and 4 of 72 , respectively). The prevalence of $C$. mitsukurii appeared related to the ovarian condition of the mature host, and was lower on crabs with ovaries in the early stages of development than in the later stages $\left\{G_{H}=11.24, \mathrm{p}<0.025, \mathrm{df}=4\right)$. The intensity of infestation did not, however, differ between ovarian conditions (ANOVA, $F=0.46, \mathrm{p}>0.75, \mathrm{df}=4,202$ ).
On several occasions worms were observed migrating into the newly laid clutch of the host. The migration did not always occur immediately after oviposition; in some cases, large female worms were found on the gills of crabs bearing eggs during the middle of their embryogenesis. Worms were also observed moving towards the epimeral suture of crabs in the late pre-molt condition. The infestation pattern of the worms did not, however, change with the molt condition of the host (prevalence: $G_{H}=2.89, p>0.20, \mathrm{df}=2$; intensity: ANOVA, $F=0.31, \mathrm{p}>0.70, \mathrm{df}=2,205$ ).

The prevalence and intensity of infestation of the nemerteans varied seasonally (Fig. 11A). A peak in the prevalence of infestation occurred from October to February, and a nadir from March to July. The nadir coincided with a dramatic decline in salinity (compare Figs. 7 \& 11A). Salinity and temperature were both correlated with the abundance of Carcinonemertes mitsukurii. The minimum monthly salinity was highly correlated with the mean intensity of infection (Spearman rank, $r_{s}=0.808, p<0.01, d f=10$ ), but not with the prevalence of infection $\left(r_{s}=0.308\right)$. In contrast, the minimum monthly temperature was correlated with the prevalence of infection $\left(r_{s}=0.650, p<0.05, d f=10\right)$, but not with the mean intensity of infection $\left(r_{s}=0.462\right.$, not significant).

The prevalence of Choniosphaera indica on ovigerous hosts was $85.2 \%$, and intensity ranged from 1 to 1821 female copepods. The copepod was not found in the clutches of the ovigerous Sacculina granifera-infected crabs. There was a distinct seasonal pattern in the prevalence of infestation of C. indica (Fig. 11B); not surprisingly, it resembled that of the proportion of ovigerous crabs in the population. The seasonal pattern in intensity was similar to that of prevalence but had sharper peaks.

Other parasites (e.g. Ameson sp., Hematodinium sp.) were observed in Portunus pelagicus but they did not occur at high enough levels to examine their possible affects on host reproduction, or their presence was not correlated with any of the reproductive parameters (e.g. Levinseniella sp., tetraphyllidean larva).

\section{DISCUSSION}

\section{Egg mortality, castration, and parasites}

There are 3 important ecological implications of infection by Sacculina granifera on the reproductive ecology of Portunus pelagicus. (1) Infected crabs may not necessarily have a reproductive potential of zero. While infection by parasitic castrators or parasitoids can effectively remove the host from the reproductive population (see Kuris 1974), in the 
(A) Carcinonemertes mitsukurii

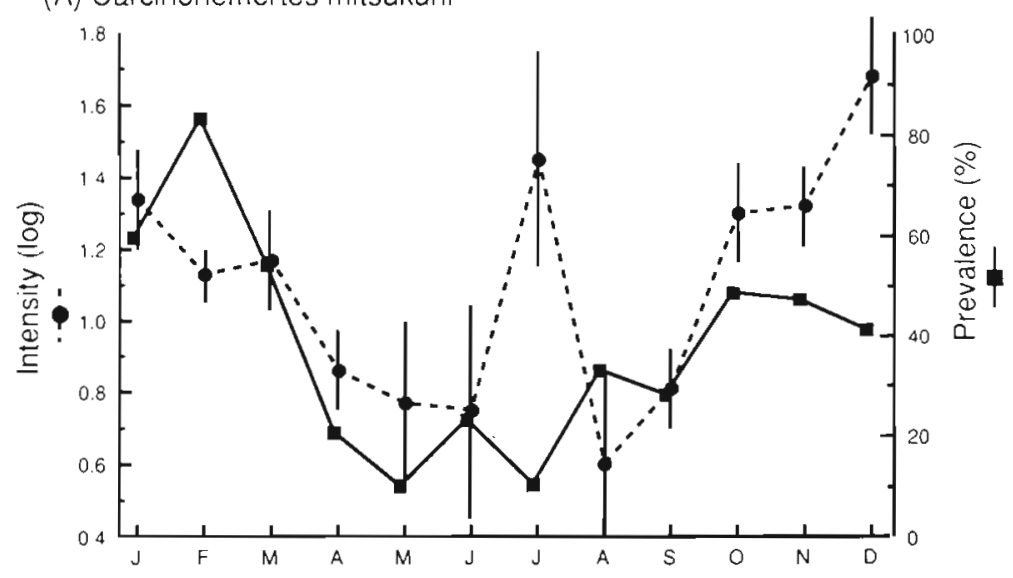

(B) Choniosphaera indica

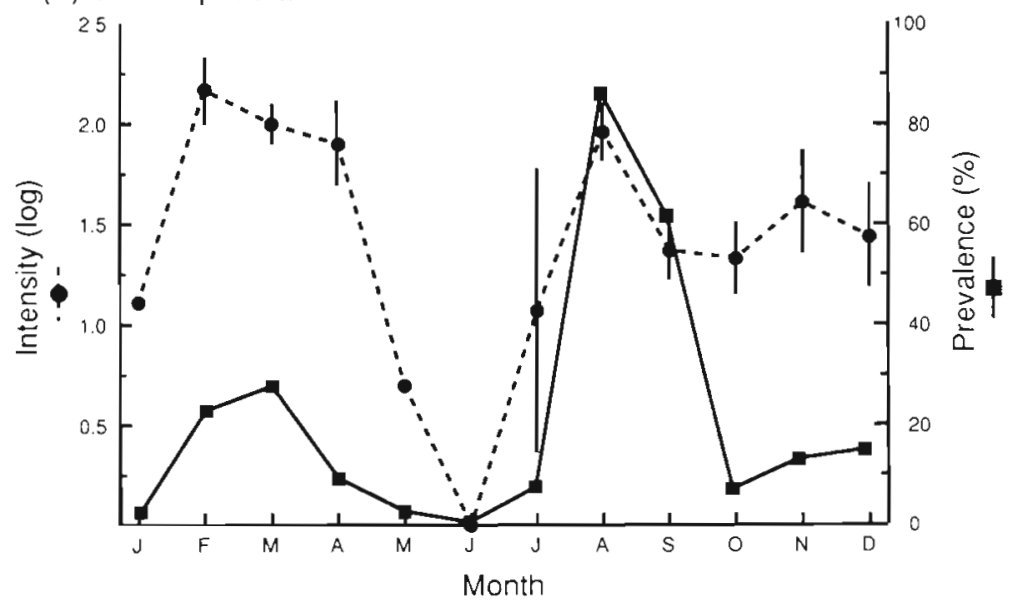

Fig. 11 Seasonal fluctuation in (A) the prevalence and mean intensity of Carcinonemertes mitsukurii on the gill lamellae and egg clutches of the mature female crabs, and (B) the prevalence and mean intensity of Choniosphaera indica in the clutches of the ovigerous crabs. The prevalence of the copepod is based on the number of mature female crabs. Bars represent SE of the mean

S. granifera-P. pelagicus association, some host reproduction may occur, albeit at a significantly reduced contribution. (2) Infected female crabs mate. If prevalent, fully castrated females may remove or distract the number of mates available to the uninfected female population. Since male crabs are polygynous, the impact of their mating with infected females on the host population may be diminished. Nevertheless, a proportion of female crabs may not be fertilized if the prevalence of the parasite is high. Two cases of infertile egg clutches were observed in the present study. (3) Uninfected male crabs may attempt to mate with castrated males (J.D.S. pers. obs.) and castrated males may mate with uninfected females (Bishop \& Cannon 1979). The latter 2 observations need further confirmation but their implication is that there may be yet a greater impact of the parasite on the reproduction of the host population.
The effect of Sacculina granifera on the fished population is high. Thomson (1951), Lester (1978) and Weng (1987) suggest removing or marketing infected crabs as they no longer reproduce, and only serve as a reservoir for further infections. Female Portunus pelagicus and males under 150 $\mathrm{mm}$ LCW are protected from the fishery in Moreton Bay. Since many of the castrated crabs are undersize or resemble females, they are also protected (Weng 1987). Recent studies of the outbreaks of nemertean worms and rhizocephalans on red king crab stocks suggest that the fishing of females and parasitized crabs may reduce the impact of the outbreaks, especially in relatively closed sys-tems such as those present in fjords, and possibly estuaries (Kuris \& Lafferty 1992). We believe that Moreton Bay may be an ideal location for such a large scale manipulation of the fishery to determine if the prevalence of the rhizocephalan can be decreased through a long term program of destroying or marketing infected crabs. An appropriate time to initiate a control program would be during the peak in prevalence of the sacculina externa, i.e. the reproductive season of the parasite.

Consistent seasonal fluctuations in the prevalence of Sacculina granifera have been noted in the summer (Weng 1987) and early winter (Sumpton et al. 1989a, present study). Phillips \& Cannon (1978), however, found no seasonal differences in prevalence, but their study was biased by small sample sizes, and incomplete sample periods. Their contention that sacculina externae are more abundant in seaward stations and that sacculina internae are more abundant in inshore stations is based on one sample area (\#2) with only 2 out of 19 infected crabs $\left(G_{H}\right.$-test with Sample 2 included $=11.7$, $\mathrm{p}<0.05, \mathrm{df}=3 ; G_{H}$-test without Sample $2=0.6, \mathrm{p}>0.05$ $\mathrm{df}=3 ; \mathrm{n}=9,19,33,19$ ).

The egg predator Carcinonemertes mitsukurii had little if any effect on the broods of Portunus pelagicus. There was no correlation between worm abundance and egg mortality of the host. This may be because the population of $C$. mitsukurii on $P$. pelagicus never reached the high levels reported for nemertean infections on populations of the Alaskan red king crab (Kuris et al. 1991), the Dungeness crab (Wickham 1986), the shore crab Hemigrapsus oregonensis (Shields \& Kuris 1988a), or the American lobster (Campbell \& Brattey 1985). There are 2 plausible ex- 


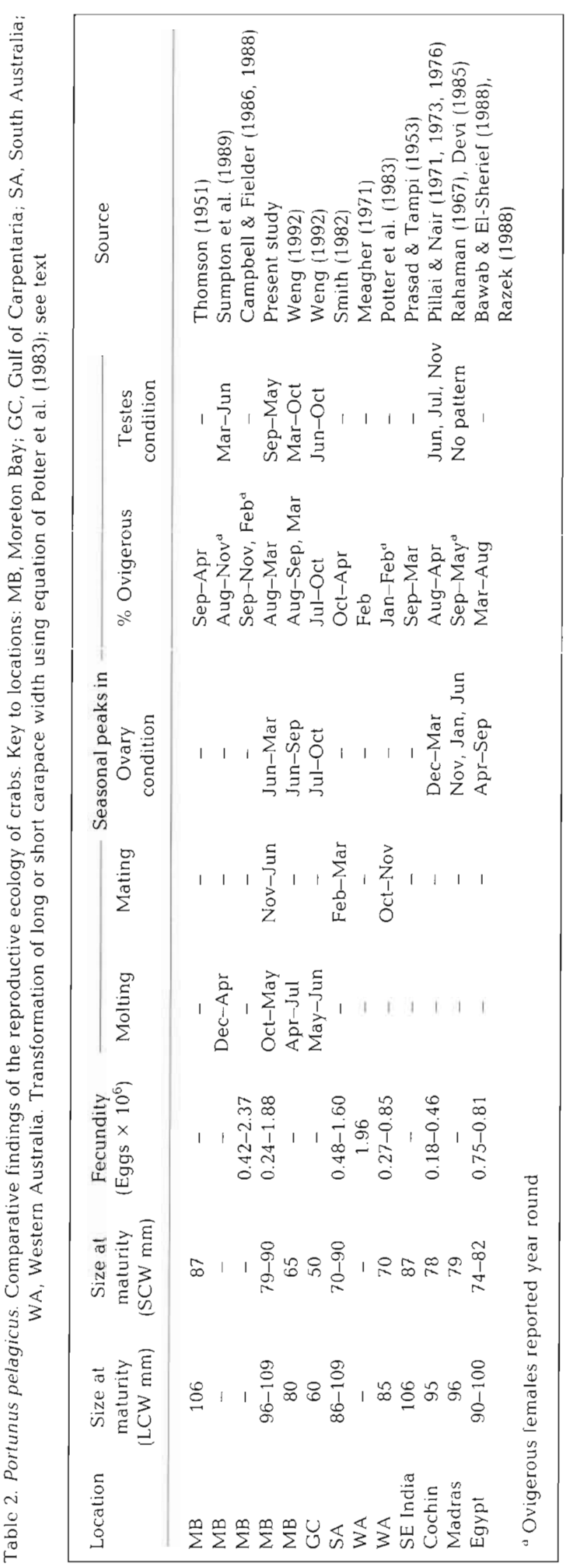

planations. Firstly, the worms are affected by seasonal changes in the temperature and salinity of Moreton Bay. Salinity affects the survival of Carcinonemertes errans on Cancer magister (McCabe et al. 1987) and laboratory-held Carcinonemertes mitsukurii (R. Gould \& J. D. S. unpubl. data), and temperature affects the survival of Carcinonemertes epialti on Cancer anthonyi (Shields \& Kuris 1988b). Secondly, the duration of host embryogenesis is short in $P$. pelagicus (Campbell \& Fielder 1986), and worms may not reproduce or feed quickly enough to cause significant egg mortality before host eclosion. Host embryogenesis plays a major role in the abundance and dispersion of Carcinonemertes spp. (Shields in press), but, until now, only hosts with a moderate to long duration of embryogenesis have been examined for egg mortality. We predict that epidemics of Carcinonemertes mitsukurii will be of short duration or will not occur on estuarine populations of $P$. pelagirus because of the effect of salinity and temperature on the nemerteans.

We found that the nicothoid copepod, Choniosphaera indica, was the major source of egg mortality on Portunus pelagicus. The copepod did not, however, have a significant impact on the broods of its host (mean mortality due to the copepod was estimated at $2.54 \%$ ). It may, however, be capable of rapid development or amplification in the ovigerous host population as observed by the lack of a lag in the patterns of prevalence and intensity compared with that of ovigerous females. Further, the occurrence of copepodites in the egg masses and gills of the crabs suggests that infestation may occur shortly after the parasite hatches. Observable egg mortality may result from the rapid build up of the parasite, or a high rate of egg predation by it. It has considerable potential to impact on the host population because egg mortality reached up to $19.6 \%$ of the clutch in heavy infestations (>500 copepods).

\section{Host reproduction}

The size at maturity of Portunus pelagicus is consistent between geographic locations when corrected for differences in carapace measurements (Table 2). Maturity is attained in a $20 \mathrm{~mm}$ range of 70 to $90 \mathrm{~mm}$ SCW (85 to $106 \mathrm{~mm} \mathrm{LCW}$ ) for both male and female crabs, with the exception of a few crabs from the Gulf of Carpentaria. In the Gulf of Carpentaria, the structure of the mature female population has shifted such that females mature at a smaller size (Weng 1992). The cause of the shift in the population structure is unknown, but differences in habitats, water temperature, salinity or fishing pressures may account for the variation in mature sizes of crabs (Tagatz 1968, Campbell \& Fielder 1986, Weng 1992).

Molting and mating in Portunus pelagicus are tightly 
linked. Females molt then mate immediately with intermolt males (Fielder \& Eales 1972, present study). Mating occurs in the austral summer and fall. In Western Australia, however, mating occurs in the spring (Potter et al. 1983). Mating in P. sanguinolentus also occurs in the fall in Moreton Bay (Sumpton et al. 1989b). Mating of the related Callinectes sapidus occurs in the boreal summer and fall (Van Engel 1958) with over $97 \%$ of the females becoming inseminated (Wenner 1989).

Gonad condition shows seasonal variation between geographic locations (Table 2). The semiquantitative index used in the present study clearly showed the progression of ovarian development with season. The gonosomatic index used by Rahaman (1967) and Sumpton et al. (1989a) is based on the weight of the gonad divided by the body weight of the crab. Their index shows a marked variance that obscures the seasonal patterns of gonad development, especially in small sample sizes. Nevertheless, female Portunus pelagicus have a peak in their ovarian development in mid-winter; and this is common to other large portunids (Wenner 1989, Sumpton 1990).

The sex ratio in the present study was considerably different from that reported previously for Portunus pelagicus from Moreton Bay. Thomson (1951) found that males were more abundant in the bay, but there was no trawl fishery at that time, and females may enter pots at considerably different rates than males (Sumpton et al. 1989a). Phillips \& Cannon (1978) found that the sex ratio was not significantly different than $1: 1$ in 4 different areas of Moreton Bay, and Weng (1992) found a 1:1 ratio in the Gulf of Carpentaria. The abundance of females in the present study may be because female crabs prefer shallow while males prefer deeper waters (Potter \& Sumpton 1987); the collection site was a relatively shallow embayment or subestuary of Moreton Bay. In Western Australia, the catches are female-dominated from December to May, with an equal ratio from June to September, then male-dominated in October and November (Potter et al. 1983).

There is a wide range in the reported fecundities of Portunus pelagicus (Table 2). Campbell \& Fielder (1986) found that differences in fecundity result from a decreased potential between successive broods in the same instar. They base their conclusion on differences between laboratory-held animals but no data are given. Laboratory-held crabs are, however, known to produce fewer eggs than those captured in the field even when well fed (Shields et al. 1991). The differences in reported fecundities may be due, in part, to small sample sizes of ovigerous females (e.g. Pillai \& Nair 1971, 1976, Sumpton et al. 1989a), smaller successive broods (Campbell \& Fielder 1986) or differences in water regime (Meagher 1971, Smith 1982).
In summary, the rhizocephalan barnacle, Sacculina granifera, had a marked impact on the reproductively active population of $P$, pelagicus in Moreton Bay. The barnacle affected individual hosts through the retardation of chelar growth, inhibition of the molt cycle, and castration. It affected the host population through castration and sterile mating, hence, loss to the reproductive population of a relatively large number of crabs. In contrast, the egg predators, Carcinonemertes mitsukurii and Choniosphaera indica, had a minimal impact on the fecundity of their hosts. The predators were only modestly abundant, and, at least for the nemertean, abundance appeared regulated by the seasonal fluctuations in salinity and temperature.

Acknowledgements. We thank Tim Anderson, James Davis, Chris Earley, Ray Giddins, and Rob Gould for technical support. Jack Kelly and Jim Campbell ably fished for crabs. Con Boel, Julie Shields, Profs Colin Dobson, R. J. G. Lester and M. Lynch helped in many ways. Many thanks to Chris O'Brien for temperature and salinity data from Toondah Harbor, Moreton Bay for 1988 to 1990 . This study was funded by an Australian Research Council grant (\#AA8931718) to J.D.S. and R. J G. Lester, and a University of Queensland Postdoctoral Fellowship to J.D.S.

\section{LITERATURE CITED}

Bawab, F. M., El-Sherief, S. S. (1988). Stages of the reproductive cycle of the female crab Portunus pelagicus (L., 1758) based on the anatomical changes of the spermatheca (Decapoda Brachyura, Portunidae). Crustaceana 54: $137-148$

Bishop, R. K., Cannon, L. R. G. (1979). Morbid behaviour of the commercial sand crab, Portunus pelagicus (L.), parasitized by Sacculina granifera Boschma, 1973 (Cirripedia: Rhizocephala). J. Fish Dis. 2: 131-144

Campbell, A., Brattey, J. (1985). Egg loss from the American lobster. Homarus americanus, in relation to nemertean Pseudocarcinonemertes homari, infestation. Can. J. Fish. aquat. Sci. 43: 772-780

Campbell, G. R., Fielder, D. R. (1986). Size at sexual maturity and occurrence of ovigerous females in three species of commercially exploited portunid crabs in S.E. Queensland. Proc. R. Soc. Queensl. 97:79-87

Campbell, G. R., Fielder, D. R. (1988). Egg extrusion and egg development in three species of commercially important portunid crabs for S.E. Queensland. Proc. R. Soc. Queensl. 99: $93-100$

Devi, S. L. (1985). The fishery and biology of crabs of Kakinada region. Indian J. Fish. 32: 18-32

Drach, P. (1939). Mue et cycle d'intermue chez les Crustacés Décapodes. Ann. Irıst. Océanographie 19: 103-391

Fielder, D. R., Eales, A. J. (1972). Observations on courtship, mating and sexual maturity in Portunus pelagicus (L. 1766) (Crustacea: Portunidae). J. nat. Hist. 6: 273-277

Gnanamuthu, C. P. (1954). Choniosphaera indica, a copepod parasitic on the crab Neptunus sp. Parasitology 44: $371-378$

Haefner, P. A. Jr (1985). The biology and exploitation of crabs. In: Provenzano, A. J. Jr (ed.) The biology of the Crustacea, Vol. 10. Academic Press, Orlando, p. 111-166

Humes, A. G. (1942). The morphology, taxonomy, and bio- 
nomics of the nemertean genus Carcinonemertes. [11. Biol. Monogr. 18: 5-105

Johnson, P. T. (1980). Histology of the blue crab, Callinectes sapidus: a model for the Decapoda. Praeger Publishers, New York

Kuris, A. M. (1974). Trophic interactions: similarity of parasitic castrators to parasitoids. Q. Rev. Biol. 49: 129-148

Kuris, A. M. (1975). Biology of decapod Crustacea. In: Smith, R. I., Carlton J. T. (eds.) Light's Manual: intertidal invertebrates of the central California coast, 3rd edn. University of California Press, Berkeley, p. 378-384

Kuris, A. M., Blau, S. F., Paul, A. J., Shields, J. D., Wickham, D. E. (1991). Infestation by brood symbionts and their impact on egg mortality in the red king crab, Paralithodes camtschatica, in Alaska: geographic and temporal variation. Can. J. Fish. aquat. Sci. 48: 559-568

Kuris, A. M., Lafferty, K. D. (1992). Modelling crustacean fisheries: affects of parasites on management strategies. Can. J. Fish. aquat. Sci. 49: 327-336

Lester, R. J. G. (1978). Marine parasites costly for fishermen. Australian Fish. 37 (Sept.): 32-33

Margolis, L., Esch, G. W., Holmes, J. C., Kuris, A. M., Schad, G. A. (1982). The use of ecological terms in parasitology (report of an ad hoc committee of the American Society of Parasitologists). J. Parasitol. 68: 131-133

McCabe, G. T., Emmett, R. L., Coley, T. C., McConnell, R. J. (1987). Effect of river-dominated estuary on the prevaience uf Cartinunemertes errans, añ equg prodator of the Dungeness crab, Cancer magister. Fish. Bull. NOAA 85: $140-142$

Meagher, T. D. (1971). Ecology of the crab Portunus pelagicus (Crustacea: Portunidae) in south Western Austalia. Ph.D. thesis, Univ. West. Australia

Phillips, W. J., Cannon, L. R. G. (1978). Ecological observations on the commercial sand crab, Portunus pelagicus (L.), and its parasite, Sacculina granifera Boschma, 1973 (Cirripedia: Rhizocephala). J. Fish Dis. 1: 137-149

Pillai, K. K., Nair, N. B. (1971). The annual reproductive cycles of Uca annulipes, Portunus pelagicus and Metapenaeus affinis (Decapoda: Crustacea) from the South-west coast of India. Mar. Biol. 11: 152-166

Pillai, K. K. Nair, N. B. (1976). Observations on the breeding biology of some crabs from the southwest coast of India. J. mar. biol. Ass. India 15: 754-770

Potter, I. C., Chrystal, P. J., Loneragan, N. R. (1983). The biology of the blue manna crab Portunus pelagicus in an Australian estuary. Mar. Biol. 78: 75-87

Potter, M. A., Sumpton, W. D. (1987). Sand crab research report. Queensland Fishing Industry Research Advisory Council 6. Fisheries Research Branch, Queensland Department of Primary Industries

Prasad, R. R., Tampi, P. R. S. (1953). A contribution to the biology of the blue swimming crab Neptunus pelagicus (Linnaeus) with a note on the zoea of Thalamita crenata Latreille. J. Bombay Nat. Hist. Soc. 51: 674-689

Rahaman, A. A. (1967). Reproductive and nutritional cycles in the crab, Portunus pelagicus (Linnaeus) (Decapoda: Brachyura of the Madras coast. Proc. Indian Acad. Scl. 65: $76-82$

Razek, F. A. A. (1988). Some biological studies on the Egyptian crab Portunus pelagicus (Linnaeus, 1766). Acta Adriatica 29: 133-144

Shields, J. D. (1992). The parasites and symbionts of the crab, Portunus pelagicus, from Moreton Bay, eastern Australia. J. crust. Biol. 12: $94-100$
Shields, J. D. (in press). The infestation and dispersion patterns of Carcinonemertes spp. (Nemertea) on their crab hosts. Hydrobiologia

Shields, J. D., Kuris, A. M. (1988a). An in vitro analysis of egg mortality in Cancer anthonyi: the role of symbionts and temperature. Biol. Bull. 174: 267-275

Shields, J. D., Kuris, A. M. (1988b). Temporal variation in abundance of the egg predator Carcinonemertes epialti (Nemertea) and its effect on egg mortality of its host, the shore crab. Hemigrapsus oregonensis. Hydrobiologia 156: $31-38$

Shields, J. D., Okazaki, R. K., Kuris, A. M. (1991). Fecundity and the reproductive potential of Cancer anthonyi in southern California. Fish. Bull. NOAA 89: 299-305

Smith, H. (1982). Blue crabs in South Australia - their status, potential and biology. South Australia Fishing Council Adelaide, Australia 6: 6-9

Smith, G. S., Sumpton, W. (1987). Sand crabs a valuable fishery in south-east Queensland. The Queensland Fisherman 5: $13-15$

Sokal, R. R., Rohlf, F. J. (1981). Biometry, 2nd edn. Freeman and Company, San Francisco

Stephenson, W. Campbell, B. (1959). The Australian portunids (Crustacea: Portunidae). III. The genus Portunus. Aust. J. mar. Freshwat. Res. 10: 84-124

Sumpton, W. (1990). Biology of the rock crab Charybdis natator (Herbst) (Brachyura: Portunidae). Bull. mar. Sci. 46: $425-431$

Sumpton, W., Potter, M. A., Smith, G. S. (1989a). The commercial pot and trawl fisheries for sand crabs (Portunus pelagicus L.) in Moreton Bay, Queensland. Proc. R. Soc Queensland 100: 89-100

Sumpton, W., Smith, G. S., Potter, M. A. (1989b). Notes on the biology of the portunid crab, Portunus sanguinolentus (Herbst), in subtropical Queensland waters. Aust. J. mar Freshwat. Res. 40: 711-717

Tagatz, M. E. (1968). Biology of the blue crab, Callinectes sapidus Rathbun, in the St. John's River, Florida. Fish. Bull U.S. $67: 17-32$

Thomson, J. M. (1951). Catch composition of the sand crab fishery in Moreton Bay, Australia. Aust. J. mar. Freshwat. Res. 2: $237-244$

Van Engel, W. A. (1958). The blue crab and its fishery in Chesapeake Bay. I. Reproduction, early development, growth and migration. Comm. Fish. Rev. 20:6-17

Weng, H. T (1987). The parasitic barnacle, Sacculina granifera Boschma, affecting the commercial sand crab, Portunus pelagicus (L.), in populations from two different environments in Queensland. J. Fish Dis. 10: 221-227

Weng, H. T (1992). Sand crab (Portunus pelagicus (Linnaeus)) populations of two different environments in Queensland. Fish. Res. 13: 407-422

Wenner, E. L. (1989). Incidence of insemination in female blue sand crabs, Callinectes sapidus. J. crust. Biol. 9: 587-594

Wickham, D. E. (1986). Epizootic infestations by nemertean brood parasites on commercially important crustaceans. Can. J. Fish. aquat. Sci. 43: 2295-2302

Williams, M. J. (1982). Natural food and feeding in the commercial sand crab Portunus pelagicus Linnaeus, 1766 (Crustacea: Decapoda: Portunidae) in Moreton Bay, Queensland. J. exp. mar. Biol. Ecol. 59: 165-176

Williams, M. J. (1986). Evaluation of anchor tags for marking the commercial sand crab, Portunus pelagicus (L.) (Portunidae: Decapoda). Aust. J. mar. Freshwat. Res. 37. $707-712$

Manuscript first received: July 22, 1992

Revised version accepted: December 7, 1992 